\title{
Sequential development of Buddenbrockia plumatellae (Myxozoa: Malacosporea) within Plumatella repens (Bryozoa: Phylactolaemata)
}

\author{
Charles McGurk*, David J. Morris, Alexandra Adams \\ Institute of Aquaculture, University of Stirling, Stirling FK9 4LA, UK
}

\begin{abstract}
Colonies of the freshwater bryozoan Plumatella repens collected from a river in the UK were found to be infected with the myxozoan parasite Buddenbrockia plumatellae following laboratory maintenance. Optimisation of the bryozoan diet allowed maintenance of infected colonies for $90 \mathrm{~d}$, permitting observation by light and electron microscopy of the sequential parasitic developmental cycle. Parasite stages were associated with host peritoneum, identifying the primary developmental phase. The association of $B$. plumatellae cells with peritoneal basal lamina and morphological similarities between parasite and host suggested that the parasite remodelled host tissue. Progressive expansion and elongation of individual parasites led to the release of freely floating vermiform stages within the host coelomic cavities. Within these 'worms', intraluminal masses developed, resulting in the formation of spores. Upon maturation, the 'worms' ruptured, releasing many spores within the host that were subsequently discharged. Although parasitism led to increased bryozoan fragmentation and lowered statoblast production, some colonies did survive, resulting in repeated waves of infection. Long-term laboratory maintenance of infected bryozoan colonies could provide a means of maintaining B. plumatellae for study until the full life cycle is ascertained.
\end{abstract}

KEY WORDS: Myxozoa · Malacosporea · Bryozoa $\cdot$ Buddenbrockia plumatellae · Development · Remodel

\section{INTRODUCTION}

The phylum Myxozoa Grassé, 1970 comprises over 1350 spore-forming species, infecting mainly aquatic invertebrates and lower vertebrates (Kent et al. 2001), with limited reports in mammals and birds (Canning \& Okamura 2004). Buddenbrockia plumatellae Schröder, 1910 and Tetracapsuloides bryosalmonae Canning, Tops, Curry, Wood and Okamura, 2002 have been classified within the myxozoan class Malacosporea. Malacosporeans have been characterised as producing softwalled spores within freshwater bryozoans (Bryozoa: Phylactolaemata), with $T$. bryosalmonae also being the causative agent of proliferative kidney disease in salmonid fish (Canning et al. 1999).

In naming Buddenbrockia plumatellae, Schröder (1910) alluded to an earlier description from 1850 by
Dumortier and van Beneden of similar vermiform parasitic stages within (Alcyonella) Plumatella fungosa Pallas. Consideration of its writhing motility and the recognition of 4 longitudinal blocks of muscle fibres allied B. plumatellae with the Metazoa (Schröder 1912). Okamura (1996) described a myxozoan parasite in Cristatella mucedo Cuvier, which formed free-floating spore sacs within the bryozoan coelom. This parasite was named Tetracapsula bryozoides, the type species of the newly formed genus (Canning et al. 1996). Morris et al. (2002) observed by light microscopy the development of vermiform parasites of a Buddenbrockia sp. that, upon maturation, released malacosporean spores within colonies of Plumatella repens that had been previously exposed to cell suspensions of brown trout kidney infected with Tetracapsuloides bryosalmonae. An ecological and ultrastructural study 
focused on the development of $B$. plumatellae in populations of $P$. fungosa, Hyalinella punctata Hancock and Fredericella sultana Blumenbach (Canning et al. 2002). However, some details of the developmental cycle within bryozoans remained to be revealed; in particular, the presence of stages preceding coelozoic 'worm' development. Despite contrasting morphologies, molecular evidence led to a proposed synonymy of B. plumatellae and T. bryozoides (Monteiro et al. 2002), with the former name assuming historical precedence.

The aim of the present study was to examine developmental stages of Buddenbrockia plumatellae within individual specimens of Plumatella repens. Repeated examination by light microscopy allowed the first description of prolonged sequential development in living hosts. Ultrastructural analysis of infected bryozoan tissue gave further insights into the morphological characteristics of the interaction between this unusual myxozoan parasite and host.

\section{MATERIALS AND METHODS}

Collection and observation of bryozoan colonies. In June 2002, floating branches and areas of plastic sheeting were collected from various locations in the River Avon, Wiltshire, UK (5100' 09" N, $\left.1^{\circ} 44^{\prime} 41^{\prime \prime} \mathrm{W}\right)$. These were examined grossly using a $\times 10$ hand lens for bryozoans. Bryozoan colonies were transported in aerated plastic containers to the laboratory in Stirling, where they were attached to Petri dishes and maintained at $21^{\circ} \mathrm{C}$ on a diet of algae and protozoa following the method of Morris et al. (2002). The bryozoans were identified as Plumatella repens by colony and statoblast morphology (Mundy 1980). Plates with adhered infected colonies were transferred to plastic beakers, and 41 of mixed algal suspension at peak growth were concentrated by centrifugation at $2600 \times$ $g$ for 20 min before being resuspended in 11 of Chalkley's medium (1.7 mM NaCl, $50 \mu \mathrm{M} \mathrm{KCl}, 50 \mu \mathrm{M} \mathrm{CaCl}_{2}$ ). The colonies were examined daily for signs of parasitism using a dissecting microscope (SZ30, Olympus) and an inverted microscope (CK2, Olympus) with attached $35 \mathrm{~mm}$ camera (SC35, Olympus) or video camera (F15, Panasonic) for recording of parasitic development.

Ultrastructural examination of Plumatella repens. At 3 sampling times, 6 samples of bryozoan zooids displaying different stages of infection were removed from the main colony by dissection. Uninfected colonies of $P$. repens were also examined as negative controls. The tissue was fixed in $2.5 \%$ glutaraldehyde fixative for 2 to $4 \mathrm{~h}$ at $4^{\circ} \mathrm{C}$, post-fixed in $1 \%$ osmium tetroxide, dehydrated through an ascending acetone series and embedded in Spurr's resin. Semi-thin $(0.5 \mu \mathrm{m})$ sections of the resin blocks were cut, stained with toluidine blue and examined by light microscopy. Ultra-thin (90 nm) sections were cut, placed on 200 mesh formvar-coated copper grids and stained with uranyl acetate and lead citrate. The grids were examined at $80 \mathrm{kV}$ using a Philips 301 transmission electron microscope.

\section{RESULTS}

\section{Examination of live Plumatella repens colonies by light microscopy}

Recognition of Buddenbrockia plumatellae infection

In the $14 \mathrm{~d}$ following collection, vermiform stages of up to $2 \mathrm{~mm}$ in length (Fig. 1a), consistent with descriptions of Buddenbrockia plumatellae (Canning et al. 2002), were recognised within 4 independent bryozoan colonies. Over the next $14 \mathrm{~d}$, more colonies were recognised to be infected, including early signs of parasitism within an individual bryozoan zooid. Study of the resulting colony revealed the sequential development of $B$. plumatellae as described below. Infected colonies thrived only after concentration of algal suspensions and were subsequently observed for $90 \mathrm{~d}$. Sequential developmental stages observed are summarised in Table 1.

Table 1. Timescale of Buddenbrockia plumatellae infection observed within Plumatella repens. After Day 30, multiple parasitic stages were present due to synchronous waves of infection

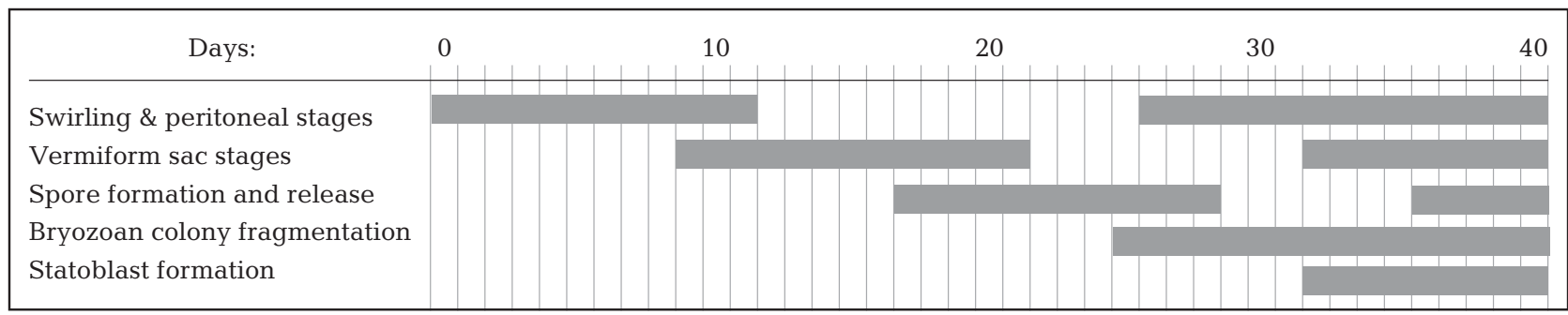



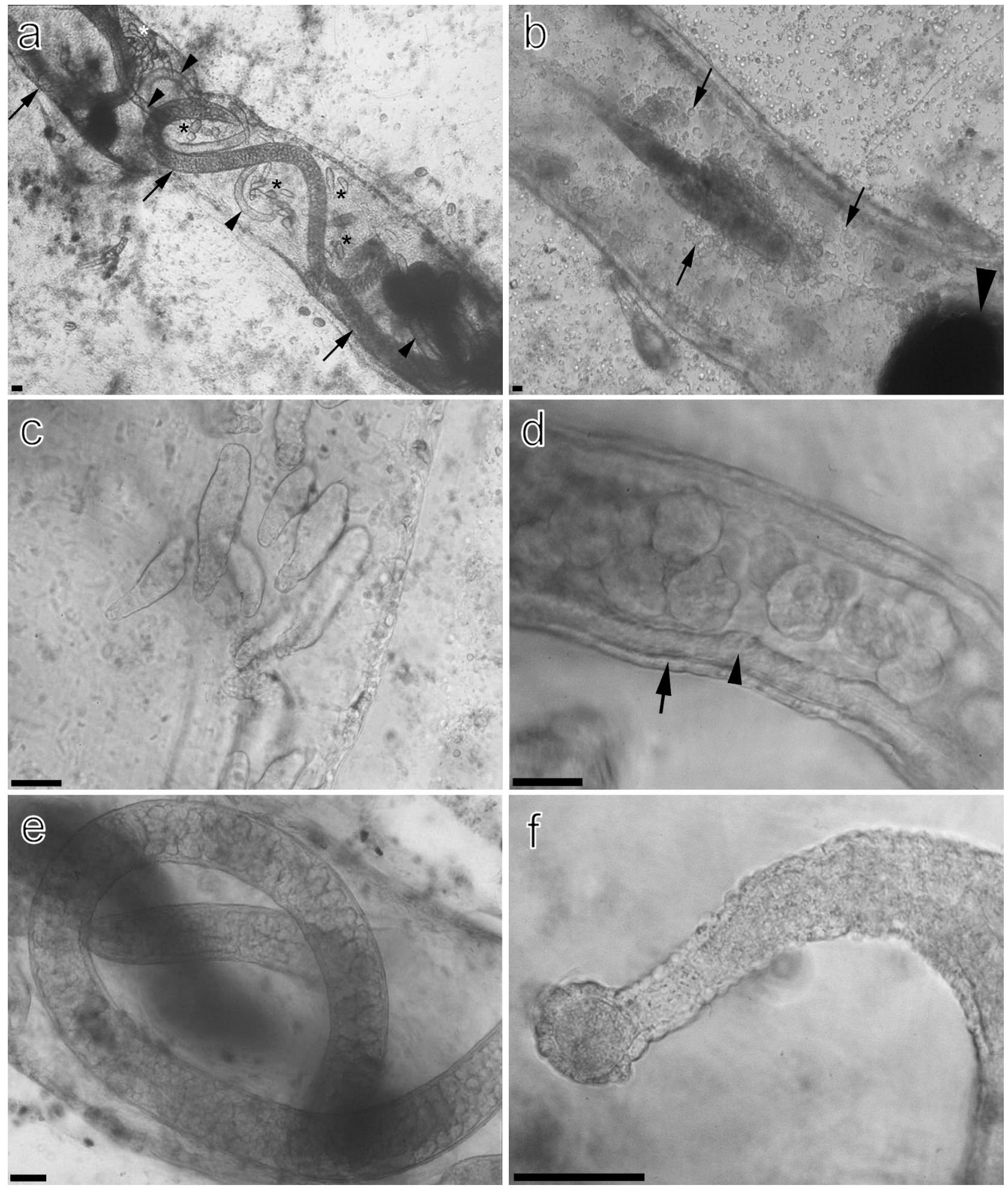

Fig. 1. Photomicrographs of Buddenbrockia plumatellae within Plumatella repens. All scale bars = $50 \mu \mathrm{m}$. (a) Early peritoneal-bound stages (*), immature 'worms' (arrowheads) and mature 'worms' (arrows) are synchronously present. (b) Early stages (arrows) attached to the peritoneum of zooid containing a statoblast (arrowhead). (c) Pyriform stages attached to peritoneum by thin proximal tips. All the stages swayed in unison within coelomic currents. (d) 'Worm' comprising outer (arrow) and inner (arrowhead) mural layers and multiple luminal masses. (e) A more mature 'worm' displaying ridged luminal appearance.

(f) Bulbous scalloped tip of a 'worm' 
Days 0 to 8: early swirling and budding peritoneal stages

On Day 0 (initial recognition of infection), numerous irregularly shaped particles of diameter 2 to $7 \mu \mathrm{m}$ circulated within the main bryozoan coelomic cavity (metacoel), while spheroid buds of diameter 30 to $50 \mu \mathrm{m}$ could also be seen attached to the bryozoan peritoneum (Fig. 1b). On Day 5, translucent oblong structures were attached to the internal bryozoan body wall by irregularly shaped tips (Fig. 1c) and were seen to sway within host coelomic currents. The parasites reached approximately $200 \mu \mathrm{m}$ in length before becoming detached from the peritoneum. On Day 8, coelozoic vermiform structures measured up to $300 \mu \mathrm{m}$, each with a defined body wall surrounding an empty lumen.

Days 9 to 19: vermiform stages including internal masses

Irregularly round bodies of diameter 15 to $40 \mu \mathrm{m}$ moved freely within some 'worms' (Fig. 1d). Aggregates of these internalised bodies were evident on Day 10 within parasitic 'worms' of up to $700 \mu \mathrm{m}$ in length. The number of internalised masses-of increasing uniformity and regularity-continued to increase, almost completely filling the lumina on Day 14. The internal structures coalesced, giving a distinctive ridged appearance (Fig. 1e), while scalloped projections were noted at the proximal tips of some 'worms' (Fig. 1f). On Day 17, numerous 'worms' of up to $1 \mathrm{~mm}$ in length were seen to be packed full of developing spores (Fig. 2a). The parasitised bryozoan colony consisted of 2 zooids at this time.

\section{Days 20 to 24: spore formation}

Twenty days after the first signs of infection, numerous malacosporean spores (mean diameter $=17.67 \mu \mathrm{m}$, $\mathrm{n}=29$; $\mathrm{SD}=0.75$ ) were swirling within the colony now comprising 4 zooids. Each spheroid spore possessed outer valve cells, 4 spherical polar capsules and 2 sporoplasms (Fig. 2b). The spores were present in all parts of the bryozoan coelom including the mesocoel close to the ciliated crown of tentacles (lophophore). Upon retraction of the lophophore, spores were rapidly ejected into the surrounding medium. Within $12 \mathrm{~h}$ of appearance, spores were no longer present within the bryozoan.

Developmental stages, including peritoneal bodies, immature sacs and mature 'worms' could be seen synchronous to spore production. Intact 'worms' were never observed being expelled from bryozoans.
Days 25 to 31: fragmentation of the bryozoan colony

On Day 25, pinching of the peritoneum was observed between 2 adjacent zooids in the colony. By the following day, the stenosis of the metacoel between the zooids was more pronounced, leaving a connecting channel of approximately $60 \mu \mathrm{m}$ in diameter (Fig. 2c). This connection remained patent, with numerous parasitic stages disseminating from the established infected part of the colony to the distal extremities of new bryozoan growth. By Day 28, the communication channel had been sealed, resulting in bryozoan fragmentation. However, signs of ongoing parasitism were evident in each of the 2 newly demarcated colonies. Despite the high parasitic burden and segregation, the resulting bryozoan colonies continued to grow, with 10 zooids being present on Day 31.

\section{Days 32 to 77 : statoblast formation and ongoing waves of infection}

On Day 32, immature statoblasts were attached to the funiculus of one of the zooids. At this time, developmental stages of Buddenbrockia plumatellae of diameter 10 to $20 \mu \mathrm{m}$ could be seen attached to host peritoneum. Multiple stages of parasitic development, ranging from small swirling particles to maturing spore sacs, were concurrently present.

By Day 34, stenosis of bryozoan peritoneum occurred at multiple locations. On Day 45, mature statoblasts were seen in several parts of the infected bryozoan colonies in conjunction with overt signs of infection, including the presence of small swirling particles of diameter 2 to $7 \mu \mathrm{m}$ and irregularly round and elongated stages of length 50 to $150 \mu \mathrm{m}$ (Fig. 2d). On Day 62 , there were clear macroscopic differences between infected and uninfected Plumatella repens colonies, the latter acting as effective negative control specimens. The infected area was more heavily fragmented with fewer statoblasts than an uninfected population of $P$. repens that adhered to the same Petri dish (Fig. 2e). The infected colonies became increasingly fragmented over the following $14 \mathrm{~d}$. None of the colonies studied survived beyond Day 77.

\section{Examination of semi-thin sections of Plumatella repens}

Within the metacoel of individual bryozoans were multiple 'worms' of varying maturity, ranging from immature stages possessing empty lumina to mature sacs filled with spores containing 2 conspicuous sporoplasms (Fig. 2f). The walls of the immature sacs were composed 

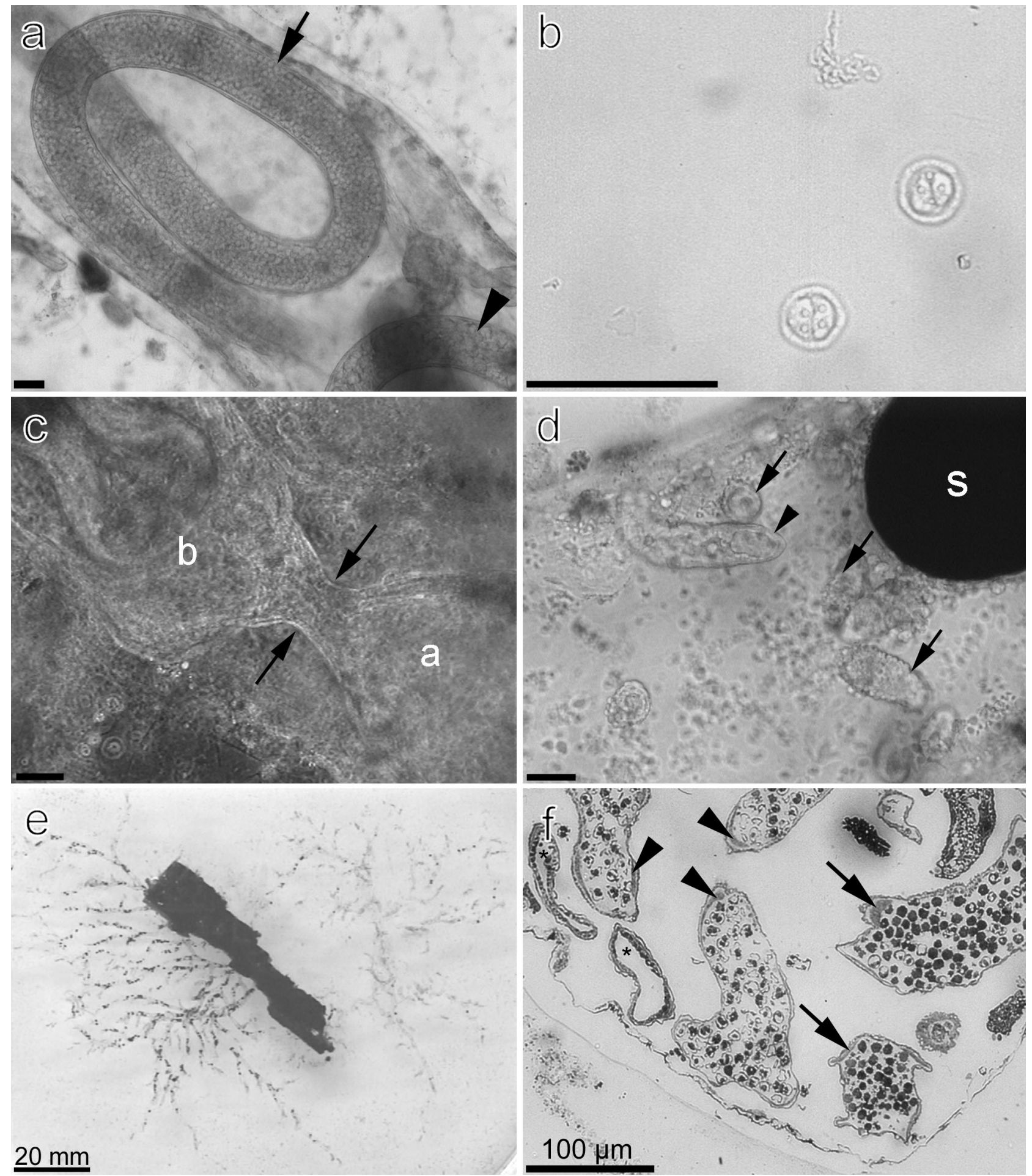

Fig. 2. Photomicrographs of Buddenbrockia plumatellae within Plumatella repens. Scale bars $=50 \mu \mathrm{m}$, unless otherwise marked. (a) An immature 'worm' (arrowhead) similar to those in Fig. 1e and a mature 'worm' (arrow) containing spores are present. (b) Released spores include 4 spherical polar capsules and 2 sporoplasms. (c) The metacoel becomes stenotic (arrows) between 2 adjacent zooids. B. plumatellae material passed from Zooid a to the newly formed Zooid b. (d) Peritoneal-bound (arrows) and vermiform stages (arrowhead) are seen in conjunction with bryozoan statoblast (s) formation. (e) Uninfected colonies are present to the left of a fragment of bark. The infected colonies to the right appear fragmented with less statoblast formation (black dots). (f) Toluidine-blue-stained, semi-thin section. Empty immature sacs (*) alongside more mature sacs containing predominantly immature (arrows) or mature (arrowheads) spores are present. Each arrow point denotes a muscle block 

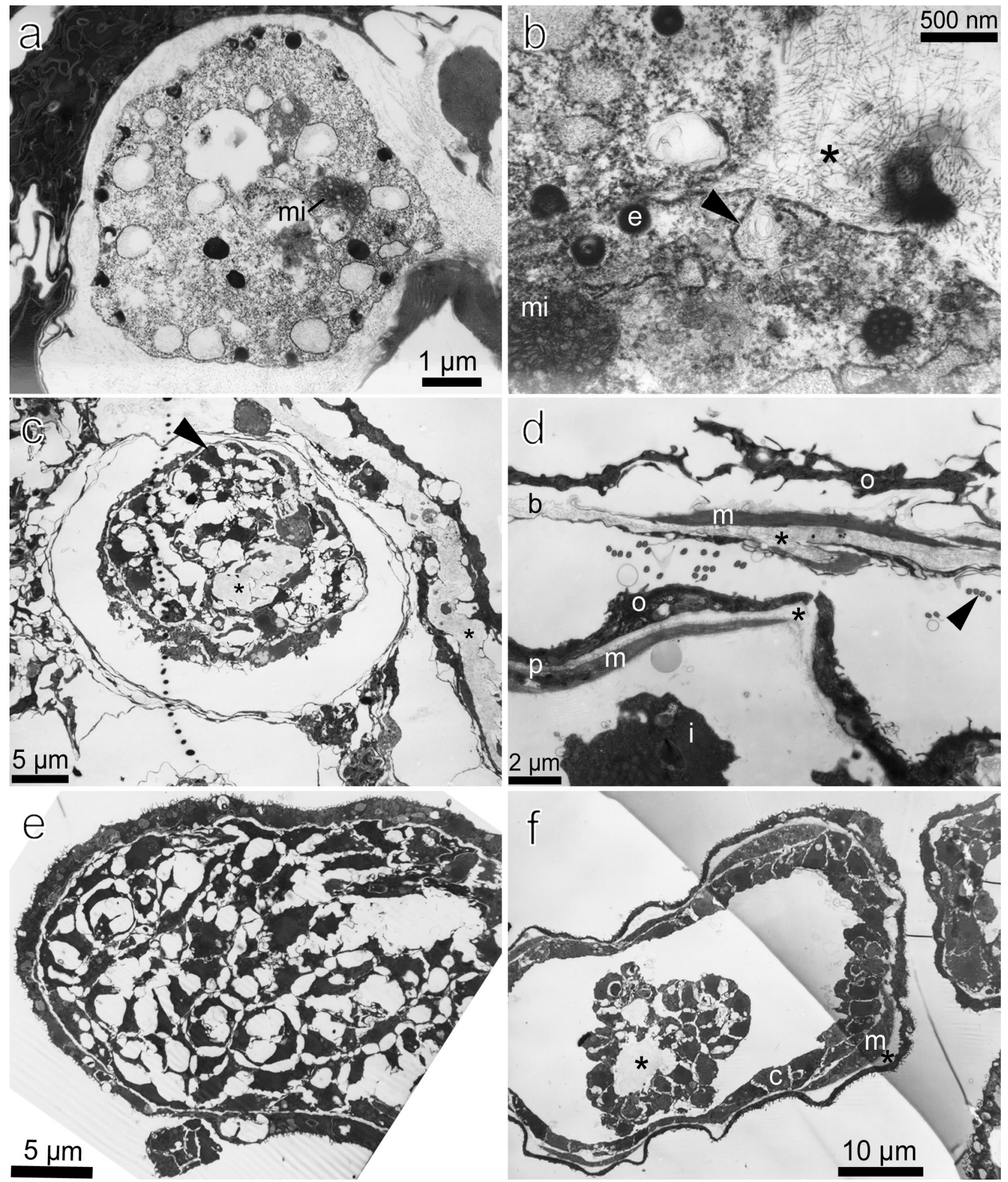

Fig. 3. Electron micrographs of Buddenbrockia plumatellae within Plumatella repens (uranyl acetate \& lead citrate). (a) B. plumatellae cell surrounded by host basal lamina. (b) Apparent communication of vacuole (arrowhead) of parasitic cell with host basal lamina. (c) Mass of acuminate parasitic cells (arrowhead) within bryozoan tissue. (d) Comparison of parasitic and bryozoan membranes, including cilia (arrowhead). (e) Immature sac containing many acuminate cells. (f) Cross-section of 'worm', including intraluminal mass and distinct mural layers (*: basal lamina; b: bryozoan tissue; c: mural cell; e: electron-dense body; i: immature spore; m: muscle block; mi: mitochondrion; o: outer membrane; p: parasite tissue) 
of 3 defined layers: the outermost being a fine sinuous membrane, the middle composed of muscle blocks interspersed by connective tissue and the innermost constituted a layer of polygonal cells. As sacs developed, intraluminal aggregates of cells could be seen, with more mature sacs containing irregularly round solidly stained rudimentary spores of diameter 6 to $9 \mu \mathrm{m}$. Increased spacing between the 4 longitudinal muscle blocks correlated with the loss of the internal layer of polygonal mural cells. Multiple larger 'worms' could be seen containing both dark-stained immature spores and lucent mature spores of diameter 10 to $15 \mu \mathrm{m}$.

\section{Ultrastructural examination of Plumatella repens}

Putative malacosporean stages within bryozoan tissue

Throughout the bryozoan body wall were electronlucent cells (Fig. 3a), comparable with those of Buddenbrockia plumatellae in Plumatella fungosa described by Canning et al. (2002) and with cells seen in the walls of developing 'worms' described below. Such cells were not recognised in the negative controls. Each cell contained a single granular nucleus with a dense nucleolus, multiple vacuoles, distinctive mitochondria and numerous electron-dense bodies (some crescent-shaped). These pale cells were intimately associated with the host peritoneal basal lamina, with the vacuolar contents showing similar staining. Communication between some parasitic vacuoles and the surrounding host basal lamina was observed (Fig. 3b).

In one area of infected bryozoan body wall, a demarcated mass was observed (Fig. 3c), with a delimiting layer composed of vacuolated cells possessing external projections. The internal content of the mass was composed of an irregular network of acuminate cells, vacuolated cells, occasional electron-lucent cells and discrete accumulations of basal lamina. The mass was surrounded by fine strands of host tissue forming a pseudocapsule.

\section{Comparison of bryozoan and malacosporean tissue}

Striking similarities in the mural architecture between the bryozoan peritoneum and the parasite spore sac could be discerned where the two were in close proximity (Fig. 3d). Both organisms featured an outer mural layer with external projections (although less conspicuous in bryozoan tissue), a layer of basal lamina and discrete muscle blocks. The presence of cilia - not recognised in myxozoans (Lom \& Dyková 1995) - allowed identification of host bryozoan tissue, while spores confirmed the myxozoan tissue.
Immature spore sacs

The lumina of early immature spore sacs contained acuminate cells (Fig. 3e). The external walls contained vacuolated cells with copious external dactylate projections. Some of the mural vacuoles appeared electron-lucent, while others contained homogenous electron-dense material. In some of these immature spore sacs, a layer of basal lamina could be seen aggregated around the internal periphery.

In more advanced spore sacs, no acuminate cells were evident within the lumina; however, defined mural cell layers could be discerned (Fig. 3f). The outer layer featured the characteristic external projections; a layer of basal lamina was positioned between the outer layer and muscle blocks enclosing a defined internal layer of polygonal cells. Within some sections, accumulations of cells could be seen within the otherwise empty lumina. The majority of these intraluminal cells appeared morphologically similar to the cells comprising the inner layer of the wall of the 'worm', with discrete zones of basal lamina also apparent in the mass. In other sections, multiple intraluminal cells of diameter 0.9 to $6 \mu \mathrm{m}$ could be seen, some apparently budding from inner mural cells (Fig. 4a). Subsequently, the inner mural layer of cells regressed, and division of cells into regular triads of round cells of diameter $6 \mu \mathrm{m}$ was observed (Fig. $4 \mathrm{~b}$ ). In more developed sacs, immature spores $(7 \mu \mathrm{m})$ were present in conjunction with small round cells $(1.5 \mu \mathrm{m})$ (Fig. $4 \mathrm{c})$. In transverse section, 4 discrete muscle blocks were noted in the wall of each sac. In all of the developmental stages, the outer wall of the 'worm' remained consistent in structure, showing external dactylate projections and vacuolation, although the vacuoles were more electron-lucent in later stages. In some maturing spore sacs, recognisable myxozoan spores (including polar capsules) were present in tandem with immature spore stages, implying that these stages were sequential and that the developmental cycle culminated at this point (Fig. 4d).

\section{Mature spore sacs}

Mature spores were contained within thinly walled vermiform sacs (Fig. 4d), with occasional spores seen outside the sacs in the bryozoan metacoel (Fig. 4c). An inner layer of longitudinal muscle blocks contained multiple mitochondria with distinctive tubular cristae, while between the 2 layers was a matrix forming the basal lamina. Occasional pale cells were interspersed between the more abundant dense cells of the external mural layer (Fig. 4e). These former cells possessed less prominent external projections, although they contained numerous electron-dense inclusions and vacuoles, including contents similar to the adjacent basal lamina. 


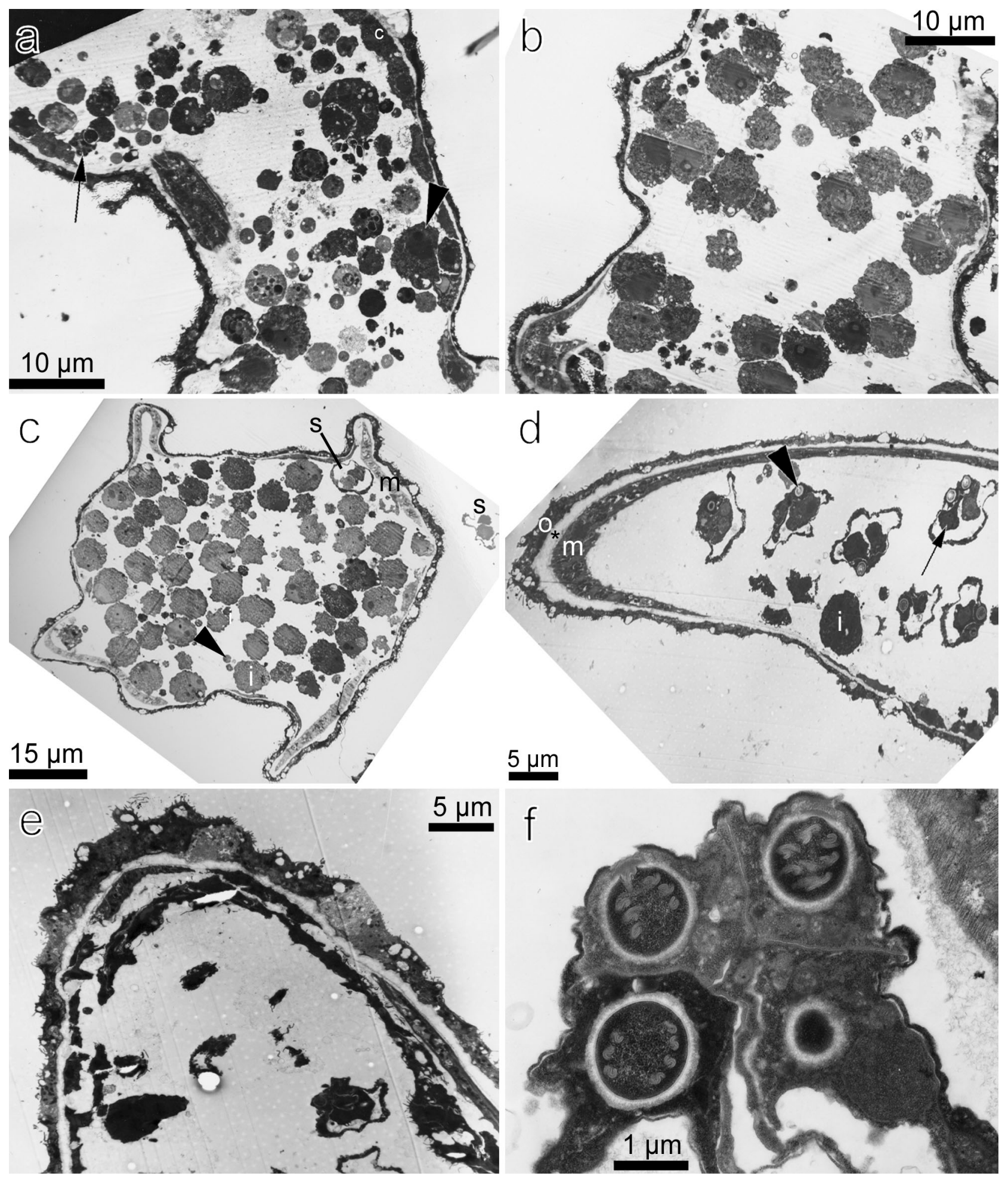

Fig. 4. Electron micrographs of Buddenbrockia plumatellae within Plumatella repens (uranyl acetate and lead citrate). (a) 'Worm' with thin mural layers and various intraluminal cells. One is budding from the inner wall (arrowhead), while another is dividing by fission (arrow). (b) Triads of developing intraluminal cells. (c) Cross-section of 'worm', including many immature spores and smaller fragments (arrowhead). (d) Upon maturity, 'worms' include mature spores with polar capsules (arrowhead) and sporoplasms (arrow). (e) The outer membrane of the 'worm' features some pale cells with multiple external projections. (f) Mature spore showing polar capsules with up to 4 polar filament turns within the plane of section (s: mature spore; other abbreviations see Fig. 3) 
Spores

Within mature 'worms' were multiple spores exhibiting up to 4 spherical polar capsules and 2 sporoplasms each (Fig. 4f). Each mature spherical polar capsule (diameter $1.4 \mu \mathrm{m}$ ) was encompassed by an electronlucent outer halo and consisted of a dense granular central matrix containing a coiled polar filament of thickness $50 \mathrm{~nm}$. Up to 4 turns of the filament could be seen within the spores examined, each turn appearing as paired sigmoid flexures as the filament passed through the plane of section. The polar capsules were contained within capsulogenic cells, which met in a central linear articulation.

\section{DISCUSSION}

Laboratory maintenance of Plumatella repens infected with Buddenbrockia plumatellae has revealed previously unidentified details of parasitic development within this host. Consistent with the other named malacosporean, Tetracapsuloides bryosalmonae, numerous small swirling coelomic particles were the earliest sign of infection (McGurk et al. 2006), representing either primordial parasitic cells or host-derived lymphocytes (Mano 1964). Conclusive identification of these cells would be intrinsic in future investigations of the early pathogenesis of infection.

Canning et al. (2002) observed cells bearing myxozoan characteristics within the body wall of Plumatella fungosa and suggested that Buddenbrockia plumatellae undergoes primary development within the host epithelium. In the current light and electron microscope studies, myxozoan cells were observed connected with bryozoan peritoneum, showing a particular association with host basal lamina. The electron-lucent cells observed within bryozoan tissue bore similarities to both mural cells of developing $B$. plumatellae 'worms' and previously described malacosporean cells (Canning et al. 1996, 2000). The encapsulated mass observed within bryozoan tissue could represent proposed intraperitoneal stages (Canning et al. 2002), the formative bryozoan developmental stage of B. plumatellae.

Morphological similarities between bryozoan and malacosporean mural tissue, including the presence of organised zones of basal lamina, lead to the proposition that the parasite may utilise host tissue during development. The parasitic worm Schistosoma mansoni Sambon, 1907 has been shown to acquire an extensive range of host antigens that are subsequently expressed on the parasite tegument (Abath \& Werkhauser 1996). Study of the development of the myxozoan parasite Myxobolus pendula Guilford, 1966 has shown an association of the growth of parasitederived cysts with degradation of host connective tissue and remodelling of fibrillar collagen (Martyn et al. 2002). These authors compared and contrasted the morphology of host and parasitic collagen fibres, and suggested that host material was reorganised during cyst development. To allow development, initial stages of Buddenbrockia plumatellae would be likely to either obtain products from the host as nutritional substances allowing de novo production of morphological components or the parasite could directly utilise and remodel host tissue. The latter proposition questions the suggested ancestral relationship of myxozoans with nematodes that have not been reported to remodel host tissue (Smothers et al. 1994, Anderson 2000, Okamura et al. 2002). However, the classification is not settled (Wallberg et al. 2004), with recent findings suggesting that the Myxozoa may not be related closely to any other existing phylum (Kelley et al. 2004). In light of the observed structural consistencies, further investigations should examine the possibility that malacosporeans remodel host muscle fibres in addition to basal lamina tissue.

The contents of the pyriform parasitic stages anchored to the peritoneum of Plumatella repens first described by Schröder (1912) appeared homogenous by light microscopy, with ultrastructural examination showing a predominance of acuminate cells. These cells were similar to those seen within the encapsulated parasitic mass, and also consistent with descriptions of developmental 'stellate cells' in Tetracapsuloides bryosalmonae (Canning et al. 2000, Canning \& Okamura 2004). However, unlike T. bryosalmonae, Buddenbrockia plumatellae cells were not interspersed with sporoplasmogenic cells and did not lead directly to the formation of spores, but instead represented the intermediate form between peritonealbound and unattached coelomic forms. This confirmed the observations of Canning et al. (2000) that the 2 species of malacosporeans exhibit different modes of spore development. External dactylate projections were ubiquitous across the developmental range of spore sacs in $P$. repens, unlike Hyalinella punctata and Fredericella sp., in which they were an inconsistent finding (Canning et al. 2002, Okamura et al. 2002).

It was previously noted that the inner layer of proliferative mural cells was progressively diminished as Buddenbrockia plumatellae spore sacs matured (Canning et al. 1996, 2002). Mural polygonal cells develop in the wall before being released into the cavity as intraluminal masses seen by both light and electron microscopy. This process results in mature spore sacs with relatively thin outer membranes that are capable of rupturing due to presumed increased distension of the sac at spore maturity. Previously, spontaneous 
release of intact mature $B$. plumatellae 'worms' from Plumatella fungosa has been reported to result in traumatic damage to the lophophore retractor apparatus (Canning et al. 2002). Despite extensive observations of infected colonies of Plumatella repens in the current study, no mature spore sacs were ever witnessed to spontaneously exit infected zooids and no incidence of lophophore dislocation was observed, suggesting this was not a dispersal mechanism from this host.

Free spores of Buddenbrockia plumatellae apparently exited Plumatella repens via the vestibular pore (the release route of mature statoblasts from bryozoans), correlating with observations of Morris et al. (2002). All spores were lost within $12 \mathrm{~h}$ of appearance, demonstrating that upon maturation in $P$. repens, released spores spread throughout the bryozoan metacoel before being voided into the surrounding water. The mean spore diameter of $17.7 \mu \mathrm{m}$ was less than that previously described for ornamented spores dissected from a Buddenbrockia sp. in P. repens $(19.0 \mu \mathrm{m})$ (Morris et al. 2002) and spherical spores of B. plumatellae (syn. Tetracapsula bryozoides) from Cristatella mucedo $(19.2 \mu \mathrm{m})$ (Canning et al. 1996). The linear articulation at the junction of the 4 capsulogenic cells proved consistent with the arrangement of cells in spores of Tetracapsuloides bryosalmonae (McGurk et al. 2005). Up to 4 polar filament turns were observed within spores of $B$. plumatellae within $P$. repens, whereas 5 turns have been reported in the alternative manifestation in C. mucedo (Canning et al. 1996).

The ongoing waves of Buddenbrockia plumatellae infection did not prevent continued growth of infected Plumatella repens colonies. Diseased colonies showed increased nutritional requirements, only thriving when provided with concentrated suspensions of algae and protozoa. The pinching of the peritoneum between contiguous zooids had been suggested to lead to demarcation of infected colonies, allowing newly developed zooids to remain uninfected and continue development of a clonal bryozoan line (Canning et al. 2002). However, in the current study, B. plumatellae spore sacs and mature spores were seen to pass readily through the narrowed channels before division could occur. Moreover, although the colonies became fragmented as a result of the occlusion of the metacoel, newly developed zooids invariably showed subsequent signs of $B$. plumatellae infection, leading to dissemination of infection to marginal zones of growth. It seems that stenosis is a pathological sequel, triggered by traumatic effects of the parasite on bryozoan tissue. The contrast in appearance between infected and uninfected colonies demonstrated severe bryozoan fragmentation in the former.

Whereas Schröder (1910) and Okamura (1996) described limited formation of statoblasts, respectively, in Plumatella repens and Cristatella mucedo infected with Buddenbrockia plumatellae, some later reports noted an absence of fresh statoblast production in malacosporean-infected bryozoan colonies (Morris et al. 2002, Canning et al. 2002). In the current study, statoblasts were seen in zooids that had shown signs of parasitism since their earliest developmental stages, meaning that statoblast formation could not have preceded B. plumatellae infection. Markedly fewer statoblasts were produced in infected than uninfected colonies. Malacosporean infection could potentially be harboured in these asexual stages over the winter period. Unfortunately, attempts at germinating statoblasts from infected colonies were unsuccessful (authors' unpubl. data), preventing the investigation of this potential route of transmission.

Canning et al. (2002) suggested that Buddenbrockia plumatellae could appear rapidly within bryozoans and vanish equally swiftly. While the former assertion has been supported by the current observations, the latter has been challenged by the maintenance of infection in Plumatella repens for $3 \mathrm{mo}$ and the resultant development of waves of malacosporean infection. The previous authors stated that sub-optimal laboratory culture conditions may have contributed to the premature demise of infected colonies and may have led to the previous absence of statoblast formation. In the current study, continued growth of infected bryozoan colonies was witnessed only following increased concentration of algal components in the culture medium by centrifugation. All of the cultured bryozoans - both uninfected and infected - died simultaneously after 3 mo of laboratory culture. Due to the condition of these colonies immediately preceding their demise, it seems likely that this was due to an accidental collapse in the culture system rather than a natural termination of infection.

Under ideal culture conditions, bryozoans harbouring Buddenbrockia plumatellae could be reared for extended periods, with consecutive waves of infection maintaining the presence of parasites. The observation of sequential developmental stages studied by light and electron microscopy has revealed the mechanism of development of $B$. plumatellae in Plumatella repens. The lack of transmission of infection between adjacent colonies supports evidence from Tetracapsuloides bryosalmonae that direct horizontal transmission is not a feature of malacosporean life cycles (Tops et al. 2004), while the presence of statoblast formation in infected colonies represents a potential mode of dissemination of infection. Further elucidation of the life cycles of the Malacosporea would be valuable in trying to understand the complex dynamics of these intriguing parasites. 
Acknowledgements. This study was funded by a studentship to C.McG. from the Natural Environment Research Council, Schering-Plough Aquaculture and the Fishmongers' Company. We thank L. Brown for processing tissue samples for electron microscopy. Video files illustrating developmental features of Buddenbrockia plumatellae are hosted at www.staff.stir.ac.uk/charles.mcgurk/Budd.htm.

\section{LITERATURE CITED}

Abath FGC, Werkhauser RC (1996) The tegument of Schistosoma mansoni: functional and immunological features. Parasite Immunol 18:15-20

Anderson RC (2000) Nematode parasites of vertebrates: their development and transmission. CABI Publishing, Wallingford

Canning EU, Okamura B (2004) Biodiversity and evolution of the Myxozoa. Adv Parasitol 56:43-131

Canning EU, Okamura B, Curry A (1996) Development of a myxozoan parasite Tetracapsula bryozoides gen. n. et sp. n. in Cristatella mucedo (Bryozoa: Phylactolaemata). Folia Parasitol 43:249-261

Canning EU, Curry A, Feist SW, Longshaw M, Okamura B (1999) Tetracapsula bryosalmonae $\mathrm{n}$. sp. for PKX organism, the cause of PKD in salmonid fish. Bull Eur Assoc Fish Pathol 19:203-206

Canning EU, Curry A, Feist SW, Longshaw M, Okamura B (2000) A new class and order of myxozoans to accommodate parasites of bryozoans with ultrastructural observations on Tetracapsula bryosalmonae (PKX organism). J Eukaryot Microbiol 47:456-468

Canning EU, Tops S, Curry A, Wood TS, Okamura B (2002) Ecology, development and pathogenicity of Buddenbrockia plumatellae Schröder, 1910 (Myxozoa, Malacosporea) (syn. Tetracapsula bryozoides) and establishment of Tetracapsuloides n. gen. for Tetracapsula bryosalmonae. J Eukaryot Microbiol 49:280-295

Kelley GO, Beauchamp KA, Hedrick RP (2004) Phylogenetic comparison of the Myxosporea based on an actin cDNA isolated from Myxobolus cerebralis. J Eukaryot Microbiol 51:660-663

Kent ML, Andree KB, Bartholomew JL, El-Matbouli M and 10 others (2001) Recent advances in our knowledge of the Myxozoa. J Eukaryot Microbiol 48:395-413

Lom J, Dyková I (1995) Myxosporea (Phylum Myxozoa). In: Woo PTK (ed) Fish diseases and disorders, Vol 1. CAB International, Wallingford

Mano R (1964) The coelomic corpuscles and their origin in the

Editorial responsibility: Richard Cawthorn,

Charlottetown, Prince Edward Island, Canada freshwater bryozoan, Lophopodella carteri. Sci Rep Tokyo Kyoiku Daigaku Sect B 11:211-235

Martyn AA, Hong H, Ringuette MJ, Desser SS (2002) Changes in host and parasite-derived cellular and extracellular matrix components in developing cysts of Myxobolus pendula (Myxozoa). J Eukaryot Microbiol 49: 175-182

McGurk C, Morris DJ, Bron JE, Adams A (2005) The morphology of Tetracapsuloides bryosalmonae (Myxozoa: Malacosporea) spores released from Fredericella sultana (Bryozoa: Phylactolaemata). J Fish Dis 28:307-312

McGurk C, Morris DJ, Auchinachie NA, Adams A (2006) Development of Tetracapsuloides bryosalmonae (Myxozoa: Malacosporea) in bryozoan hosts (as examined by light microscopy) and quantitation of infective dose to rainbow trout (Oncorhynchus mykiss). Vet Parasitol 135:249-257

Monteiro AS, Okamura B, Holland PWH (2002) Orphan worm finds a home: Buddenbrockia is a Myxozoan. Mol Biol Evol 19:968-971

Morris DJ, Morris DC, Adams A (2002) Development and release of a malacosporean (Myxozoa) from Plumatella repens (Bryozoa: Phylactolaemata). Folia Parasitol 49:25-34

Mundy SP (1980) Stereoscan studies of phylactolaemate bryozoan statoblasts including a key to the statoblasts of the British and European Phylactolaemata. J Zool 192: 511-530

Okamura B (1996) Occurrence, prevalence and the effects of the myxozoan Tetracapsula bryozoides parasitic in the freshwater bryozoan Cristatella mucedo (Bryozoa: Phylactolaemata). Folia Parasitol 43:262-266

Okamura B, Curry A, Wood TS, Canning EU (2002) Ultrastructure of Buddenbrockia identifies it as a myxozoan and verifies the bilaterian origin of the Myxozoa. Parasitology 124:215-223

Schröder O (1910) Buddenbrockia plumatellae, eine neue Mesozoenart aus Plumatella repens L. and Pl. fungosa Pall. Z Wiss Zool 96:525-537

Schröder O (1912) Zur Kenntnis der Buddenbrockia plumatellae Ol. Schröder. Z Wiss Zool 102:79-91

Smothers JF, von Dohlen CD, Smith LH Jr, Spall RD (1994) Molecular evidence that the myxozoan protists are metazoans. Science 265:1719-1721

Tops S, Baxa DV, McDowell TS, Hedrick RP, Okamura B (2004) Evaluation of malacosporean life cycles through transmission studies. Dis Aquat Org 60:109-121

Wallberg A, Thollesson M, Farris JS, Jondelius U (2004) The phylogenetic position of the comb jellies (Ctenophora) and the importance of taxonomic sampling. Cladistics 20: $558-578$

Submitted: March 20, 2006; Accepted: August 30, 2006 Proofs received from author(s): December 12, 2006 